\author{
七 沢 淳 ${ }^{1}$ 武 田 邦 彦 $^{2}$

\section{Concept and Theory of Separation for Recycling} \\ by Atushi NANASAWA ${ }^{1}$ and Kunihiko TAKEDA ${ }^{1}$ \\ 1. Shibaura Institute of Technology, Minato-ku, Tokyo 108
}

\begin{abstract}
The separation unit, separation factor, total flow in separation system, energy requirement, and second wastes by separation for recycling system have been studied theoretically. Theoretical equations of separation unit, and height of separation unit were introduced and it was pointed that the total flow in the separation unit was proportional inversely to the separation factor by two powers and the amount of the second waste materials is proportional to the factor. The second waste materials and the energy consumption should be considered in the aspect of the environmental assessment. The physical term and the social term have to be divided for the recycling separation more definitely than for the ordinal separation process.
\end{abstract}

KEY WORDS : Separation, Separation Unit, Total Flow, Recycling, Separation Energy, Cascade

\section{1.はじめに}

化学プロセスの内で消費されるエネルギーの約 $75 \%$ が分離に 関するものであるという試算があるように, 一般的な化学プロセ スに挍いても分離工学の寄与は格段に大きい1)。リサイクリング 分野ではその比率はさらに大きく分離工学の重要性もより高いと できる。すなわち, 天然界から産出される鉱物, 有機物などの資 源は必ずしもそのままの形で人間に有用なものとは限らないが, リサイクルの場合には，すでに人間が使用したものが対象であり， したがって平均的には自然から得られる物質と比較して化学反応 などを経ずして有用である場合が多いといえるからである。

このようにリサイクリング分野での分離工学の重要性は極めて 高いにもかかわらず分離工学が本来, 天然界から得られる資源を 対象物として理論体系, 技術体系を構築してきたので, その歴史 的な意味をも包含しているといえよう。すなわち, 分離理論は, (1)分離ユニットの構成, (2)分離ユニットの重畳状態, (3)分離の理 論エネルギーを主要な柱として極めて理論的に整備され，いわば “見事な理論体系”を有しているものである。さらに一般的な分 離の研究の多くは具体的な分離プロセスの設計, 問題点の解決な どを主眼にしており, 詳細で精緻な整理がなされている2）その 反面, 多くの理論や装置上の工夫は天然資源から精製品を取得す るための現象論的な方向に進み, 必ずしも体系化された分離理論 を考慮したものでないことも多い。今日の社会において物質やエ ネルギーのリサイクルの促進が急がれていることからリサイクル の分離工学が社会の環境を守るという倫理上の課題と密接に関係 し, これまでの金属精錬工業, 石油精製工業などのように工業的

* 1997 年 6 月 30 日受付 11 月 27 日受理

1. 正会員 芝浦工業大学大学院 地域環境システム

2. 正会員 工博 芝浦工業大学教授 工学部材料工学科

〔著者連絡先〕FAX 03-5476-3161 (芝浦工大・材料)

キーワード : 分離, 分離コニット, 総流量, リサイクル, 分離エネルギー, カス ケード
に成立するものであるか，さらに経済的に有利なものであるかを 基本的な視点として進められてきたアプローチと異なる。

本論文では天然界の資源を主たる対象とし，鉱物学，金属精錬， 化学工業, 電子工業などのなかで進歩してきた分離理論とリサイ クルの関係について, 分離ユニットの重畳形状と分離エネルギー を中心として研究した結果を述べる。特に, 分離操作が一定以上 の速度を求められたときの状態について考察した。また天然資源 からの分離プロセスにおいてもリサイクルプロセスでの分離と類 似のものもある。しかし, リサイクルプロセスにおける分離の位 置づけが天然資源からの分離や化学プロセスや半導体製造などの 分離プロセスと基本的な要請で異なることもあり, 特に本論では その差を論じることを目的としているので, 相互の差を強調して 論じた。

\section{2. 理論}

$2 \cdot 1$ リサイクルプロセスの分離ユニット

サイズ分離や浮遊選鉱, 磁気的, 電気的分離などの物理的分離, および化学平衡や反応を応用した分離は, その最小単位を 1 つの 分離ユニットに還元することができる3)。分離ユニットでは準静 的な操作のときに, 静的な分離操作で得られる “理想的分離倸数” に比例した係数を得ることができるものとして定義される。たと えば精緻に設計され純粋な物質を扱う蒸留操作の場合には，1つ の棚段でほほ完全な気液平衡を達成することができるので数少な い可視的な分離ユニットである。しかし，工業的な分離の場合， 分離ユニットは一般的に不完全であり,さらに有限の時間で分離 操作が行われるので, 分離ユニットで達成される分離係数は無限 時間経過後の分離倸数に対して低い值を示す。

しかし, 実験的に分離係数を求めるときには, 無限時間経過し た状態での係数を測定するので, 実際の分離操作では分離係数が 時間の関数になり, 分離結果を予測するうえで不都合になる。

この問題を回避するためには, 分離係数を物理的に意味の明確 


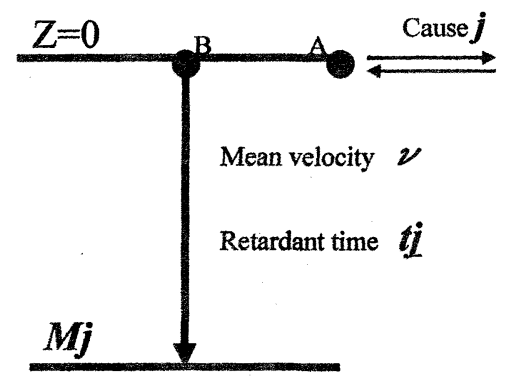

Fig. 1 Kinetics model of separation unit.

な性能とし, 分離操作条件や時間とは無関係な定義でその概念を 定め, 分離ユニットの大きさを分離操作条件や時間の関数とする ことが適切である ${ }^{4)}$

分離されるものが固体であれ，液体，気体であれ，分離装置内 を流れる物質を 2 つに分け，装置内を流れるすべての物質の平均 の速度で移動する一群と，ある特定の要因で遅れながら移動する ものを考える5)。

Fig. 1 は分離装置内のある部分（分離ユニット）の物質の基 本的な動きを示したもので，zは空間の位置， $M_{j}$ は “遅れ要因” $(j)$ による遅れ時間 $\left(t_{j}\right)$ の間に平均の速度 $(\nu)$ で動く物質群 が移動する距離である。たとえば，吸着を応用した分離方法では 吸着塔の中を平均速度で移動する物質と吸着という遅れ要素で逑 れる物質との区別を示し，ふるいでの分別では，ふるいの目を通 過して下に落ちるものとふるいの上を移動する物質群に相当する。 したがって，ここでいう “物質”とは分子の場合もあるし目に見 えるような大きなものの場合もある。ここでふるいを例に取り分 離係数と分離ユニットの大きさについての概念を示す。ふるいで は分離される物筫の精径分布に対してある網目の大きさ（開口寸 法）を持ったふるいの通過率を無限時間経過した後の状態で表す。 たとえば横軸に粒径，縦軸に通過率で示される典型的な図がそれ に相当する。しかしふるいによる分離操作で有限の時間内ではふ るいの目より小さいものもある確率でふるいの上に残る。見かけ の分離係数が分離速度に依存するが，Fig. 1 の取り扱いは速度に よる見かけ上の分離係数の変化を分離ユニットの大きさの変化と してとらえることを意味している。

ふるいの分離係数はふるいの開口寸法と分離対象の物質の寸法 によって数学的に求められる係数として定義されることが望まし く，このような定義を用いれば分離係数はふるいや吸着剈などの 分離機能材の機能に依存する值を得ることができる。さて，平均 速度と遅れ時間との関係から，遅れ距離 $M_{j}$ は式(1)で示される。

$$
M_{j}=\nu t_{j}
$$

また分離ユニット内を流れる全体の物質の数 $\left(N_{t}\right)$ に対して， 要因 $j$ で遅れる。

物質の数 $\left(N_{j}\right)$ の割合を $\xi_{j}$ とすると, その分率は,

$$
\xi_{j} \equiv N_{j} / N_{t}
$$

で示される ${ }^{6)}$ 。結局, 分離ユニットの流れ方向の大きさは分率と 遅れ距離の積となるので,

$$
H_{j}=\xi_{j} \cdot M_{j}
$$

で示される。分離ユニット内で進む反応が擬一次反応と見なしう る場合には, 遅れ要因 $j$ による遅れ時間は反応速度定数 $(k)$ の逆 数で示されるので, 式(3)で示される分離ユニットの大きさは速 度定数の逆数で示される。ここでいう「速度定数」とは化学反応 の速度定数, 拡散現象に基づく遅れ要因の速度，ふるいなどによ るふるい面を通過するある固まりの通過時間などに基づくものな ど制限はない。

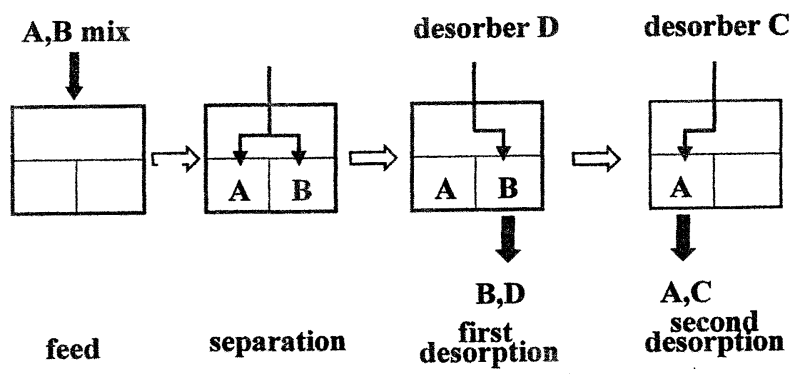

Fig. 2 Individual operation in separation unit.

式(1)から式(3)で導いた分離ユニットの高さ（分離ユニットは その高さと面積で体積が決まるが，まず高さを求める）の定義は, 蒸留, 吸収, クロマトグラフィーなどの多くの分離方法で定義さ れる分離ユニットの流れ方向の大きさと本質的に同じであるが, 特定の分離方法で使用される定数などは含まれていない。また， 化学工学では分離工学理論の普及が十分ではなくいわゆる「段プ ロセス」と「微分プロセス」に分類されることがあるが，上記の 理論展開で示されたように, 分離工学は本来元こに存在する分子, 成型品の固まりなどあらゆるものを同様に取り扱える工学である。 そのため, 上式は分離装置の種類や原理によらない。

上記に示した分離ユニットはそれ自体 1 つの装置として独立し ているときもあるが, 多くの分離装置では装置内に複数の可視的 あるいは仮想的分離ユニットを包含している。

分離ユニットで実現する分離係数は一般的に大きい方が好まし いと考えられている。たとえば, ある分離ユニットに拈いて, 分 離対象の物質 $\mathrm{A}$ と B がほぼ完全に分離されれば, 好ましい分離 ユニットと評価される。しかし, 基礎研究で実施される分離シス テムのように単純で繰り返し分離が必要ないときには分離ユニッ トの分離係数が大きい方がよいが, リサイクルプロセスのように 多種類の物質を扱うときには, 1 回の分離で目的が達せされる場 合は少ない。

分離ユニットの単位操作をさらに分解すると, Fig. 2 に示し たように, 供給, 分離, 洗浄, 脱離の 4 つの素過程から構成され ている。

分離ユニットに混合物を供給するときにはリサイクルする対象 物質以外の物質を混入しないと仮定する。また, 分離対象物質 $\mathrm{A}$ および $\mathrm{B}$ を分離ユニットから脱離するときには脱離物質として $\mathrm{C}$ および D を使用し， A, B の量に対する C, Dの比率を $a, b$ の量とする。 C, D は物質のときもあるし, 分離プロセスによっ てはエネルギーである場合もある。ここではリサイクル分離プロ 七スを可能な限り統一的に扱うことを目的としているので，C， $\mathrm{D}$ が物質であってもエネルギーであってもよいが, 以下では物質 として記述する。

リサイクル物質の分離によって新たに生じる物質の量 $Q_{T}$ は, $i$ 成分の量を $Q_{i}$ とすると次の簡単な関係によって表される。

$$
Q_{T}=a Q_{\mathrm{A}}+b Q_{\mathrm{B}}
$$

仮にリサイクルする物質の中で金属元素 $(\mathrm{A})$ のみを取り出し, 有機材料 $(\mathrm{B})$ を捨てる方法を考えてみると, リサイクルによっ て生じる新たな廃棄材料の量は, 式(4)にBを加えたものとなる。 仮に $\mathrm{B}$ と比較して A が分離機能材に対してきわめて大きな親和 性を有している場合には, 分離係数は大きくなり好ましい分離工 ニットと認識されるが, 係数 $a$ が大きいので分離ユニットの中 に残存している A を除去し, 引き続き A と B の混合物を供給す る準備に大きな負荷がかかる。この関倸はリサイクルプロセスで の分離に限定されず, 一般的分離に共通するものであるが, 後に 
述べるようにリサイクルプロセスの成立要件と特に深く関わって いることを指摘する。

C，Dが物質の場合にはこれらが新たな廃棄物にならないため に, 回収が必要とされるが，C，Dの回収操作も分離操作に他な らない。A と C, B と D の分離が蒸留などのようにエネルギー を使用し他の物質を加えない操作の場合には新たな廃亲物は発生 しないが，エネルギーの回収を要する。また工業的によく用いら れる水洗などの方法では，A と Cの分離にさらに新たな廃菓物 を生成することになる。結局, A と C の分離には新たな物質を 用いないことが可能なプロセスでは，C拈よびDの回収率を $c$, $d$ とすると, リサイクル分離システムに供給される廃棄物の全体 量に対する、リサイクル分離によって新たに発生した廃蓑物量の 合計の比率（これをりサイクル物質回収比 $\left(\gamma_{M}\right)$ と定義する） は,

$$
\gamma_{M}=\frac{a(1-c) Q_{\mathrm{A}}+(b(1-d)+1) Q_{\mathrm{B}}}{Q_{\mathrm{A}}+Q_{\mathrm{B}}}
$$

となる。係数 $b$ は分離ユニットの分離のメカニズムや分離機能 材の種類によって異なるので, 一般的な関係を求めるのは困難で あるが, 特定の分離機能材で用い, 狭い範囲の分離倸数の場合に は分離係数と係数 $b$ の間に簡単な比例関係,

$$
b=e \alpha
$$

が仮定できる。係数 $b$ は分離ユニットにおいて親和性が高い物 質を分離ユニットから取り出す場合の係数であるから, 分離係数 $\alpha$ が高くなればなるほど大きくなる。この係数の理論的取り扱い も研究されているが，あまり成功していない7)。その理由は $\alpha$ が 分離機能材, あるいは分離ユニットの稼働原理によって異なる值 をとるからであり, 本論文でも詳述を避ける。一方, 式(5)の係 数 $a$ は物質 $\mathrm{A}$ が分離ユニットに対して滞留性（分離ユニットの 稼働原理が化学的であるときには親和性や反応性であり, サイズ 分離等の場合には分離ユニットから脱離しやすいことを示す）が 小さいことを仮定しているので, 多くの場合, 分離ユニットの中 にある分離機能に無関係な体積（デッドボリューム）などの物理 的要因に支配されることが多い。したがって, 分離係数とは独立 と考えて整理することができる。また，分離ユニットから $\mathrm{A}, \mathrm{B}$ を効率的に取り出すためには C, D は A, B と類似した性質を有 していなければならず，その結果， A, B と C, D を分離すると きに分離負荷が新たにかかる結果をもたらす。すなわち少なくと も $b$ と $d$ の間には反比例の関係が存在する。

結局, $a, c$ は独立の值を取りうるとすると, リサイクル物質 回収比は,

$$
\gamma_{M}=\frac{a(1-c) Q_{\mathrm{A}}+\left(e \alpha\left(1-\frac{f}{e \alpha}\right) Q_{\mathrm{B}}\right.}{Q_{\mathrm{A}}+Q_{\mathrm{B}}}
$$

となる。たとえば $\alpha \gg 1, a \ll b$ の場合には $\gamma_{M}$ は近似的に分離 係数の 1 次に比例するので, 分離係数が大きいほど分離装置から 排出される物質の量が増大する結果となる。すなわち見かけ上は “好ましい分離ユニット”を用いたにもかかわらず，分離操作で 新たな廃充物を排出することを避けることが重要なりサイクルプ ロセスにおける分離の場合には優れた分離方法とはいえない。

$2 \cdot 2$ リサイクルプロセスの分離ユニットの総流量

分離は 1 つの分離ユニットですべての目的を達成するのは困難 であるので, 複数個の分離ユニットを組み合わせて, 目的にあっ たシステムを組み立てる必要がある。

混合物から特定の元素や化合物を取り出すための典型的な分離 システムは, Fig. 3 に示すような階段状の分離システムである。 図の最上段に示した分離ユニットで分離された分離流は, 次の段

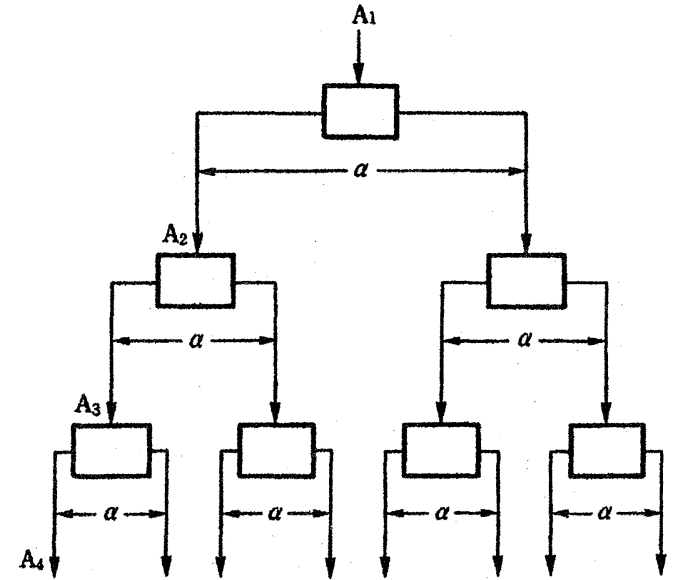

Fig. 3 Separation system for recovering highly purified materials.

の分離ユニットに供給され, さらにその段の分離流が 3 段目の分 離ユニットに供給される。

Fig. 3 で A1, A2 ‥1分離流の名称, $\alpha$ は分離流間の分離係 数であり，1つの分離ユニットで分離された物質は次の分離ユニッ トに効率的に移動する。一見，能率のよさそうに見えるこのシス テムは,リサイクルに不利なシステムの 1 つと考えられる。仮に 1 つの分離ユニットで濃縮側と減損側の流れの量が一定であると すると, 一段の分離の後, 濃縮側（分離流の片方をいい, 資源の 分離などの場合は“取得したい物質の流れ”をいうが, リサイク ルプロセスの分離の場合には “取得したい方”が存在しない。） の流量は半分になるので，たとえば 6 段の分離システムを組むと， 最終的に分離した濃縮流の量は全体の $1.5 \%$ にしかならない。

リサイクルを行う主な目的は, 廃棄物などの使用済みの製品を 資源と見なしたり，環境的視点から社会に放出することを防がな くてはならないことから, その大半を回収することを目的として いることが多い。その点では低品位鉱石から少量の特定の元素を 取り出し, 他のものは捨てる場合とは根本的に異なる。もとより リサイクルプロセスにおいても希少資源を少量回収する場合もあ るが, 回収に大量の石油エネルギーを使用し, 回収対象となる製 品より多くの物質を回収によって発生するプロセスは成立しにく い。金属資源を回収するためにその数倍の有機材料資源を消費す る場合には，(7)式の “リサイクル物質回収比”に加えて，“等資 源消費”指数のような概念を入れる必要がある。

分離ユニットの組み合わせを一般化して数学的に取り扱うこと により, 分離装置に供給した物質の大半を回収利用するシステム としては, どのような分離システムが適当かを考察する。分離工 ニットの一般的な組み合わせとその流れおよび組成を Fig. 4 に 示した。

図で $F$ は分離ユニットへの供給流, $P$ は濃縮流, $W$ は減損流, $z, y, x$ はそれぞれの分離流の濃縮成分のモル分率， $\alpha$ は分離係 数, $\beta$ は頭濃縮係数であり, 添え字 $i$ は分離ユニットの位置を示 す。このような一般化された分離システムの第 $i+1$ 段の分離流 は分離システムの外側で観測される濃縮流 $(P)$ の単位量に対し て次式で表される8)。

$$
\frac{W_{i+1}}{P}=\frac{1}{\beta-1}\left[y_{p}\left(1-\beta^{i-N}\right)+\left(1-y_{p}\right) \beta\left(\beta^{N-i}-1\right)\right]
$$

ここで, $N$ は総段数を示す。

式(8)を数值的に計算すると, 分離装置内での混合を最小に抑 


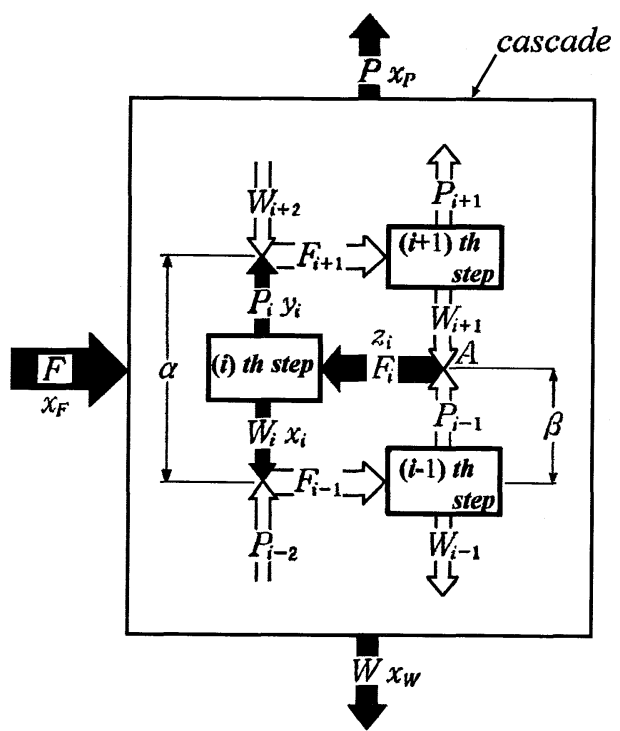

Fig. 4 General flow chart of separation unit cascade.

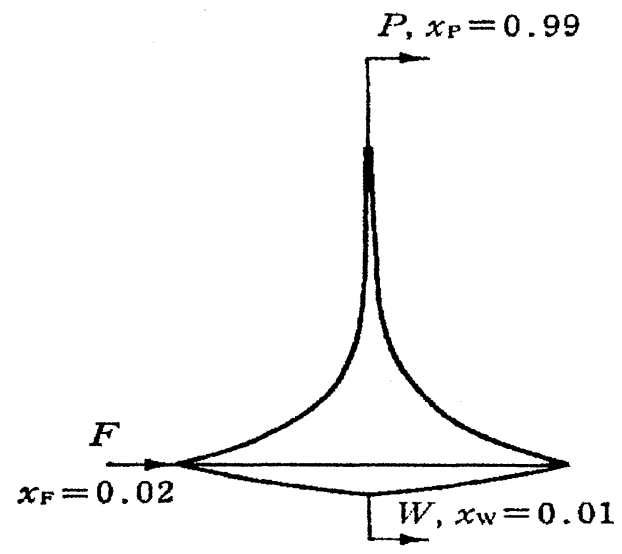

Fig. 5 Shape of separation process

制したときの分離装置の外形の列の形は組成によって異なるがそ の一例を Fig. 5 に示す。

Fig. 5 は $2 \%$ の品位の原料を分離プロセスに供給し, 回収率 $50 \%$ で $1 \%$ の品位のものを廃棄し, $99 \%$ の純度のものと製品 として取り出すときの分離装置の外形と示している。天然物から の分離取得の場合は経済的理由から原料の中に含まれる取り出し たい成分や物質のすべてを取り出さず, 経済的に最適な濃度で廃 棄物とする場合が多いが，リサイクルの場合には廃棄物の減量と いう意味でより厳しい回収率が求められることもある。

一方, Fig. 5 での分離の労力の尺度（価值関数の和： $V_{a l}$ ) は 次式に基づいて計算することができる。

$$
\begin{array}{r}
V_{a l}=\left(\left(2 x_{p}-1\right) \ln \frac{x_{p}}{1-x_{p}}\right) P+\left(\left(2 x_{w}-1\right) \ln \frac{x_{w}}{1-x_{w}}\right) W \\
-\left(\left(2 x_{f}-1\right) \ln \frac{x_{f}}{1-x_{f}}\right) F \quad \ldots \ldots \ldots \ldots \ldots \ldots \ldots \ldots \ldots \ldots \ldots
\end{array}
$$

価值関数の和 $V_{a l}$ は濃縮流，減損流および供給流の濃縮成分濃 度がそれぞれ， $x_{p}, x_{w}, x_{f}$ のときの労力の尺度であるから，こ の値を比較することにより特定の分離の困難さを表すことができ る。Fig. 5 の組成では $V_{a l}$ は 75.2 であるが，廃棄物品位を $0.2 \%$ に変更すると $V_{a l}$ は 132.9 になり, 分離の労力は相対的に約 2 倍 になることがわかる。

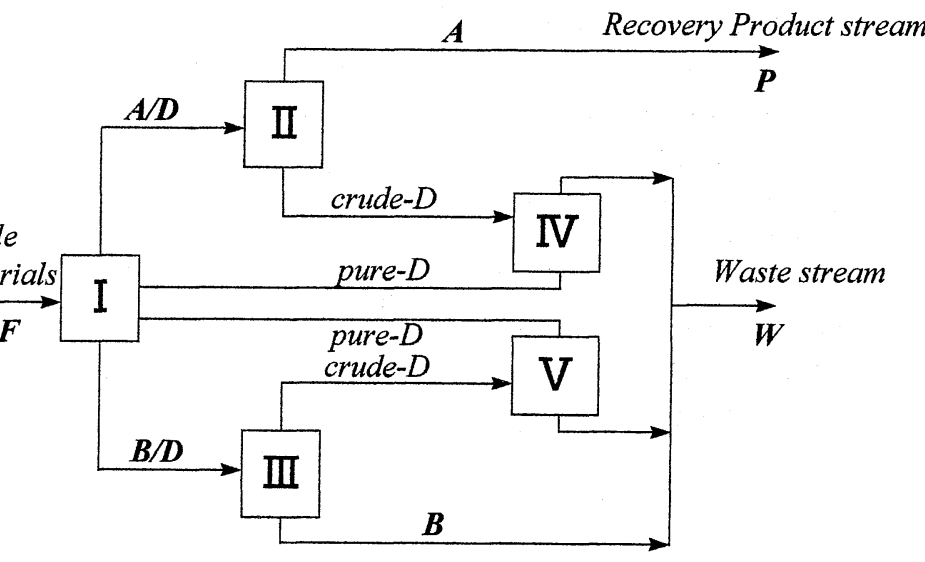

Fig. 6 Total flow of recycling separation system.

以上のように分離装置の外形は供給流，濃縮流および減損流の 濃度によってさまざまな形を取るが，天然界の資源を分離精製す るプロセスは減損側の負荷（消費されるエネルギーおよび物質の 流量など）が濃縮側の負荷よりも大きい場合が多い。これが，分 離プロセスに扔いて回収側のエネルギー損失が大きく, 廃液や廃 材の発生する原因になっている。減損側の負荷を減少させるため には，分離効率を犠牲にする必要がある。ここでは具体的な例や 式を挙げることはできないが，たとえば，Fig. 4 の一般化した分 離ユニットの組み合わせにおいて, システム内の再混合をより積 極的に認めれば廃液量を減少させるための理論的計算が可能であ る。しかし, 廃液量や減損側の負荷を提言させるためには一般的 に分離装置が巨大になり，工業的には採用されない場合が多い。

分離ユニットの分離係数も考慮に入れて分離装置内総流量を定 量的に示すと,

$$
\Sigma L=f \cdot V_{a l}
$$

でありここで $f$ は分離ユニットの物理的性能に関する頭分離係数 $\beta$ によって決まるものであり,

$$
f=\frac{\beta+1}{(\beta-1) \ln \beta}
$$

と書ける。しかし式(10)で示す総流量 $\Sigma L$ はFig. 6 に示すリサ イクル分離系の最初の分離装置 (I)の総流量に過ざず, リサイク ル分離のシステム全体の流量は, 添字 $j$ を分離システム内の $j$ 番 目の分離装置として,

$$
(\Sigma L)_{\text {Recycle }}=\Sigma\left(\Sigma L_{j}\right)
$$

で与えられる。

すなわち, Fig. 6 では装置全体の流れを簡単に示すために脱離材 は D で示したが, 分離装置 $(\mathrm{I})$ で分離された目的物 $\mathrm{A}$ 抢よび $\mathrm{B}$ は脱離材 D との分離を分離装置(II)および(III)で行う。さらに, 2 種の脱離材はプラント内の分離装置(IV)および $(\mathrm{V}) て ゙$ 精製された 後, 再び装置内で再利用される。さまざまな分離システムにおい

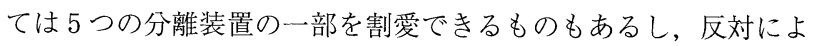
り複雑な分離システムになる分離例もある。

また，通常の分離に扔いても分離装置内総流量は式(9)で示さ れるが, 天然物からの分離の現在までの分離理論では分離対象物 をいかに効率的に分離するかということを主眼に理論研究が進ん できており, 分離装置内の総流量や分離装置から環境に排出され る溶液などの廃棄物の負荷を求める概念は個別の対策として工業 的に処理されており，理論体系や概念としては発達していない。 しかし, リサイクルプロセスに打りる分離ではもともと資源回収 や環境負荷を問題にしているのであるから, Fig. 6 のような回収 系をも含めた総流量理論と概念を構築する必要がある。この関係 
は次の分離エネルギーとの関係とあわせて総合的に考察すること が必要である。

\section{$2 \cdot 3$ リサイクルプロセスの分離エネルギー}

分離の理論的エネルギーは分離理論の体系化の中で Cohen, King らによって整理された ${ }^{9)}$ 。その後の分離理論は彼らの理論 を再整理したり，解説したりする例が多く目的物をいかに効率的 に分離するかという点に絞られている。リサイクルにおける分離 エネルギーについては，リサイクルというプロセスの社会的意義 から，そこに使用される分離エネルギーも極小にする考え方が必 要とされる。たとえば分離装置に供給される物質の大半を回収し， そこに投入される分離エネルギーも回収できることが望ましい。

従来の分離理論の取り扱いでは分離ユニットの操作が準静的に 行われた場合は，分離のエネルギーは最小仕事 $\left(E_{m \text { work }}\right)$ にな る。たとえば，モル分率 $x_{\mathrm{A}}$ である 2 成分の気体を純粋な状態で の 2 種の流れに分ける分離ユニットで消費される分離エントロピー $(\Delta S)$ は,

$$
\Delta S=-R\left(x_{\mathrm{A}} \ln x_{\mathrm{A}}+\left(1-x_{\mathrm{A}}\right) \ln \left(1-x_{\mathrm{A}}\right)\right)
$$

とできる。ここで, $R$ は気体定数である。

しかし, 準静的な分離は分離の時間がかかりすぎて工業的な意 味がない。現実の分離プロセスにおける最小仕事は分離エネルギー 全体に対して僅かな割合でしかなく, プロセスの支配的なエネル ギーは，(1)分離ユニット内で A，B 2 つの物質を接触させるエネ ルギー, (2)分離システムの還流エネルギー, の 2 つである。分離 対象となる 2 つ物質を接触させるエネルギーは液体を送るポン プ動力, ベルトコンベヤの動力などが主なものであり，その本質 的な意味は，「分離すべき物質をFig. 6 にあるような分離ユニッ トに送り込み, それによって 2 つの物質を接触させ, さらに接触 後に分離する」一連の操作に要する動力である。蒸留などの場合 には蒸留塔の圧力損失によるポンプの動力がこれに相当するし， ふるいの役目をするべルトコンベヤ上に乗せられた物質の分離の 場合にはベルトコンベヤの動力が分離対象となる材料を新しいふ るいの上に移動する動力として使われることになる。いずれにし ても, 分離物質が分離ユニットに連続的に運搬されなければ分離 ができないのは当然である。

移動のエネルギー $\left(E_{\text {move }}\right)$ は分離対象物が発生する場所から の移動 $\left(E_{r}\right)$, 工場内の移動 $\left(E_{f}\right)$ および分離装置全体の移動 $\left(E_{p}\right)$ の 3 つ分かれる。

$$
E_{\text {move }}=E_{r}+E_{f}+E_{p}
$$

この中で, $E_{r}$ はリサイクル分離の場合に特に重要であり, 使 用済みのPET ボトルを回収しょうとすると, 原油を輸送して工 場内に運ぶのと比較して, 格段の移動エネルギーを要することが 指摘されている。 $E_{f}$ は粉砕した固体や液体を輸送することが多 い天然物の移動に対して, 雑多な形状のものを取り扱うリサイク ルでは，天然物からの分離に対して大きくなる場合がある。

以上の第 1 項, 第 2 項は分離プロセスごとに異なるものである が，それに対して第 3 項は分離の理論項であり，1つの分離ユニッ 卜を通過する物質の単位エネルギー $e_{S U}$ と分離ユニットの総流量 $\Sigma L$ の積で示される。

$$
E_{p}=e_{S U} \cdot \Sigma L
$$

これに対して，還流エネルギー $\left(E_{R}\right)$ は，分離とはより高い 純度の組成のものと連続的に接触させることである, ということ から必要となり, 接触させるためには異なる状態に置かなければ ならないからである。蒸留においては気液の接触を要するのでリ ボイラーのスチームとクーラーの冷却エネルギーになる。多くの 分離プロセスでこの還流エネルギーが分離エネルギーの大半を占 める。分離ユニットの分離係数を $\alpha$ として, 分離装置の外形が箱
形の場合の最低必要な還流エネルギーは次式で示される ${ }^{10)} 。$

$$
E_{R}=\frac{x_{p}-x_{f}}{(\alpha-1) x_{f}} \cdot \lambda_{R}
$$

ここで $\lambda_{R}$ は異なる状態間の物質の転換エネルギーを示す。

このように工学的意味に扔ける分離エネルギーは移動のエネル ギーと還流のエネルギーで構成されるが，Fig. 6 に示すようにリ サイクル分離では分離装置 (I)に扔けるエネルギーのみに注目す ることはできない。したがってリサイクル分離装置内総流量に相 当する移動エネルギーと回収系の還流エネルギーを考慮すること を要する11)。分離装置全体や分離装置の一部が環境温度と異な る場合や定常的な分離操作が困難で常に温度変化を伴う場合には, 昇温や降温に伴う熱損失 $\left(E_{\mathrm{tran}}\right)$ や放熱による損失 $\left(E_{\mathrm{div}}\right)$ が ある。

$$
E_{\text {Heat }}=E_{\text {tran }}+E_{\text {div }}
$$

プロセスの温度を決める要因は反応速度を上昇させたり，分離 物質の劣化を防止するという場合もあるし，また温度差そのもの が分離ユニットの分離係数を変化させ，それを分離原理とするプ ロセスもある。また，放熱による損失もプロセスの形状や特徽に よって大きな割合を占めるときもある。

分離プロセスにおけるエネルギーは 4 種類の和として表現でき る。

$$
E_{\text {total }}=E_{m \text { work }}+E_{\text {move }}+E_{R}+E_{\text {Hear }}
$$

このように分離プロセスにおけるエネルギー消費は物質流れと 同様に分離プロセスの優劣を決める因子であり，分離エネルギー を回収し，可能な限り可逆的に分離を行うことが必要になる。特 にリサイクルに打りる分離に扔いては，分離に要するエネルギー はリサイクル自体の価值を支配することもあるし，リサイクルで 回収する物質をエネルギー源として再利用するときには，リサイ クルで使用するエネルギーが，回収されたもののエネルギーより 小さいことを要求されるのはいうまでもない。したがって, リサ イクルエネルギー回収比 $\left(\gamma_{Z}\right)$ の定義と理論研究で進める必要 がある。

\section{3. 考}

分離システムの基本的な現象の一つに, 分離の負荷は, 式(10) に示したように(1)分離ユニットが有する物理的要請（関数 $f$ ), と(2)分離したものの価值が決める社会的要素（関数 $V_{a l}$ ) に分割 できることは大変興味のあることである ${ }^{12)} 。$

分離システムの最適設計は, 分離ユニットの物理的性能と, 回 収製品濃度および廃棄物量で決定される, リサイクルプロセスの 分離システムの場合には, 従来の分離工業のように「コスト最適」 「最小分離装置」という要請よりも，「リサイクルに伴うエネルギー 最小」または「廃棄物処理の結果生じる廃棄物の量を最小にする」 という別の要請が発生する。その結果, 分離装置全体の大きさは, 式(10)では決めることができず，(3)エネルギー最小，あるいは(4) 廃棄物最小の条件を付加する必要が生じよう。

リサイクルプロセスの分離における分離エネルギーを論じる場 合には分離エネルギー回収系の概念を入れる必要があるが，これ は別の機会に示すことにする13)。天然物を分離するときに考え られる分離の最適值はリサイクルプロセスでの分離でそのまま適 用することに慎重である必要があることを指摘したい。特に社会 的要請で決まる項 $\left(V_{a l}\right)$ が天然物からの分離とリサイクル分離 で異なることは明らかである。また，物理的要因であり分離係数 に依存する項 $(f)$ は分離の性能であるから天然物の分離とリサ イクルプロセスでの分離では差がないとと考えられるが，先に示 したように分離装置内の流量は分離係数の 2 乗に反比例する項と, 
リサイクル分離に特有の分離係数に比例する項とを考慮する必要 があるので, 適切な分離装置を選択するうえでもリサイクル分離 が天然物分離と本質的に異なることが考えられよう。リサイクル プロセスにおける分離は分離理論, 概念および設計などの多くの 面でこれまで分離効率重視で進んできたものと異なることは明ら かであり, その一つ一つが今後解析されていくと考えられる。

\section{引用 文 献}

1) In discussion at 7th International Symposium of Separation Technology, Knoxville, Tenn., (1990)

2）具体的な記述で整理されている分離工学の優れた著書は多いが，たとえば，古 崎新太郎：分離精製工学入門, 学会出版センター, (1989), : Karger, B. L., Snyder, L. R. and Horvath, C. : An Introduction to Separation Science, (1973), : John Wiley and Sons, (New York) : Rousseau, R. W. : Handbook of Separation Process Technology, (1987), : John Wiley and Sons (New York) などがある。

3) Cohen, K. : Separation Process, (1947), McGraw-Hill Book Company (New York)
4）武田邦彦・市原 格・渡辺利典・小花和平一郎：化学工学会誌，Vol，15，No 3 , p. $559-566$, (1989)

5) Takeda, K. and Morita, K. : Separation Science and Technology, Vol, 31, No. 19 , p. $2655-2670$, (1996)

6) Giddings, C. : Theory of Chromatography, (1982), Marcel Dekker, (New York)

7) King, C. J. : Separation Process, (1971), McGraw-Hill Book Company, (New York)

8）武田邦彦他編：分離科学ハンドブック，(1991）, 共立出版

9）武田邦彦：高純度化分雒技術，(1997), フジテクノシステム

10) Nishigaki, Y., Onitsuka, H. and Takeda, K. : J. Nuclear Science and Technology, Vol. 89, p. 372-380, (1990)

11) Miyake, T., Takeda, K. and Obanawa, H. : Separation Science and Technology, Vol. 22, p. 963-971, (1987)

12）武田邦彦：分離のしくみ，(1992），共立出版

13) Miyake, T., Onitsuka, H., Obanawa, H. and Takeda, K. : Reactive Polymers, Vol. 87 , No. 5 , p. $63-72$, (1987) 